\title{
Training, task flexibility and the employability of low- skilled workers
}

Citation for published version (APA):

Sanders, J. M. A. F., \& de Grip, A. (2004). Training, task flexibility and the employability of low-skilled workers. International Journal of Manpower, 25(1), 73-89. https://doi.org/10.1108/01437720410525009

Document status and date:

Published: 01/01/2004

DOI:

10.1108/01437720410525009

Document Version:

Publisher's PDF, also known as Version of record

\section{Please check the document version of this publication:}

- A submitted manuscript is the version of the article upon submission and before peer-review. There can be important differences between the submitted version and the official published version of record.

People interested in the research are advised to contact the author for the final version of the publication, or visit the DOI to the publisher's website.

- The final author version and the galley proof are versions of the publication after peer review.

- The final published version features the final layout of the paper including the volume, issue and page numbers.

Link to publication

\footnotetext{
General rights rights.

- You may freely distribute the URL identifying the publication in the public portal. please follow below link for the End User Agreement:

www.umlib.nl/taverne-license

Take down policy

If you believe that this document breaches copyright please contact us at:

repository@maastrichtuniversity.nl

providing details and we will investigate your claim.
}

Copyright and moral rights for the publications made accessible in the public portal are retained by the authors and/or other copyright owners and it is a condition of accessing publications that users recognise and abide by the legal requirements associated with these

- Users may download and print one copy of any publication from the public portal for the purpose of private study or research.

- You may not further distribute the material or use it for any profit-making activity or commercial gain

If the publication is distributed under the terms of Article $25 \mathrm{fa}$ of the Dutch Copyright Act, indicated by the "Taverne" license above, 


\title{
Training, task flexibility and the employability of low-skilled workers
}

Training, task flexibility and employability

\author{
Jos Sanders and Andries de Grip
}

Research Centre for Education and the Labour Market, Maastricht

University, The Netherlands

Keywords Training, Skills training, Labour mobility, Flexible labour

Abstract This paper analyses whether low-skilled workers' training participation and task flexibility contribute to their firm-internal and firm-external mobility, and find that both training participation and task flexibility contribute only to firm-internal employability. However, the workers' participation in training plays a much more explicit role in their firm-internal career than their task flexibility does, as the former appears to be an important means to increase their opportunities in the firm-internal labour market. Neither the low-skilled workers' participation in training nor their task flexibility contributes to their external employability. Task-flexible, low-skilled workers are less likely to expect to be externally employable than non-task flexible workers are. The focus of the low-skilled workers on their firm-internal employability can be explained by the fact that such workers usually have more opportunities to improve their position in the firm-internal labour market than in the external labour market.

\section{Introduction}

In the 1990s, workers' employability received much attention from both policy makers and human resource specialists in the business community. The paradigm of lifetime employment seems to have been replaced by a new paradigm of lifetime employability marked by a high degree of flexibility. Among others, Arthur (1994), Bridges (1994) and Hyatt (1995) have characterised modern careers as "boundaryless". We consider employability to be an individual characteristic in terms of a worker's capacity and willingness to remain attractive in the labour market, that is, a worker's labour market value. This raises the question, to what extent workers can maintain or increase their employability in the labour market. In the literature on employability, two instruments are frequently mentioned: training participation and task flexibility (i.e. doing tasks that belong to other jobs). These "employability instruments" may contribute to workers' ability to remain attractive in the labour market and also signal a worker's willingness to be employable (de Grip et al., 2004).

In this paper, we test the hypothesis that training participation and task flexibility contribute to the employability of low-skilled workers. In this analysis, we distinguish between three forms of employability, namely

The authors thank Bart Golsteyn, Patrick van Eijs, an anonymous referee and the editors of this volume for their helpful comments on an earlier version of this paper. 
IJM

25,1

job-match employability, which refers to a worker's chance to remain employed in his/her current job within the current firm (same job, same employer); firm-internal employability, which refers to a worker's chance to switch to another job within the current firm; and firm-external employability, which refers to a worker's chance to switch to a job in another firm. Although the term job-match employability indicates that participation in training and task flexibility might also be important for low-skilled workers to keep up with the developments related to their current job, we expect that both training and task flexibility are more important for their firm-internal and external employability[1].

Our focus on low-skilled workers is interesting from two viewpoints. First, the labour market position of low-skilled workers is vulnerable currently as their employability is threatened because they are frequently crowded out of their traditional job domains by higher skilled workers (Borghans and de Grip, 2000). Second, low-skilled workers generally participate less often in training than skilled workers do (e.g. Shields, 1998), so one might wonder whether or not low-skilled workers deliberately invest in their employability.

We first analyse whether workers' participation in training and task flexibility affect low-skilled workers' expectations regarding their employability in terms of the three forms of employability we distinguish. Second, we analyse whether these expectations had been realised two years later. Finally, we analyse whether low-skilled workers' employability expectations induce a larger participation in training and task flexibility. This enables us to analyse whether low-skilled workers participate in training and demonstrate their task flexibility to increase the chances of realising their expectations.

For our analyses we use data from the linked 1998 and 2000 waves of the Dutch OSA Labour Force Survey. We find that both workers' training participation and task flexibility contribute only to workers' firm-internal employability. However, workers' participation in training plays a much more explicit role in workers' firm-internal careers than their task flexibility does, as the participation in training appears to be an important tool to increase their chances in the firm-internal labour market. Neither participation in training nor task flexibility contributes to the external employability of low-skilled workers. Task-flexible, low-skilled workers are less likely to expect to be externally employable than non-task-flexible workers are.

\section{Training, task flexibility and the concept of employability}

The concept of workers' employability is not new[2]. It was developed in the 1950s. However, there have been some changes in the focus of the concept in the course of time. In the 1950s and 1960s, employability was seen as an individual's potential to become employed. The attention focused on a worker's attitude to employment in general and on the self-perception the workers 
develop during their career. Influencing and adjusting attitudes and the perception that the people have of their abilities contributed to the successful labour market re-entry of people who had lost their self-confidence (Soloff and Bolton, 1969).

From 1970 onwards, attention became increasingly focused on occupational knowledge and skills instead of on a worker's attitudes. Not only basic occupational skills but also knowledge about one's possibilities (Tseng, 1972), about one's own position in the labour market (Mangum, 1976) and about the employment situation in general play crucial roles here. At the end of the 1970s, partly related to the economic recession in industrialised countries, it was realised that merely having some occupational skills is often not sufficient to remain attractive in the labour market. Hoyt (1978) acknowledged the importance of a worker's "transferable" skills, which retain their value in many different work situations. Examples of such transferable skills are the social and relational skills that are important not only to get a job, but also to keep it and to move on to another job, if necessary. Moreover, from an employee's point of view, employability became more important, since the economic recession made it harder both to find and to keep a job.

After 1980, the employability concept more and more became a meta-characteristic of workers' labour market value. This meta-characteristic combines attitudes, knowledge and skills and determines the labour market potential of workers. In this sense, employability has an important influence on a worker's career whether it is in the beginning, building or final stage (Charner, 1988).

In the 1990s the differences between the various views on employability and how it affects people increased. For some authors, only a worker's labour market potential and skills play a role. Others focus on the possibilities to use a worker's employability in organisations (Levy et al., 1992), knowledge of the labour market and policies of firms and the government (Outin, 1990), or they emphasise workers' capacity to influence their career (Bloch and Bates, 1995) and to deal with changes (Hyatt, 1995).

In order to structure the employability concept, Thijssen (1997) developed a taxonomy of the existing employability definitions. He distinguished between three types of employability definitions: a core definition, a broader definition and an all-embracing definition. According to the core definition, employability encompasses all individual possibilities to be successful in a diversity of jobs in a given labour market situation. In its core definition, employability only concerns someone's capacities.

The broader definition of employability incorporates both the capacity and the willingness to be successful in a diversity of jobs. In addition, the ability to learn is included as an asset of a worker's employability. Therefore, in the broader definition, employability encompasses all the individual
Training, task flexibility and employability 
IJM

25,1

76

characteristics that determine the current and future position in the labour market.

In the all-embracing definition, contextual factors and effectuation conditions are added. Effectuation conditions are context-bound factors that facilitate or hamper a worker's employability, such as the training provided by the firm. In the all-embracing definition, employability encompasses all individual and contextual conditions that determine a worker's current and future position in the labour market. However, the emphasis is still on workers' capacities and willingness to be proactive, which gives them a strong position in the labour market. In this paper, we therefore define a worker's employability as:

The capacity and the willingness to be and to remain attractive in the labour market, by anticipating changes in tasks and work environment and reacting to these changes in a proactive way.

It should be emphasised that employability is not a static concept, as a worker's employability can change over time. Whether or not workers are employable, in the sense that they are able and willing to remain employed, depends on a number of factors, some of which workers can and some of which they cannot easily influence directly. In this paper, we focus on two important factors that can be influenced by the workers themselves, namely their training participation and task flexibility[3]. As mentioned in the introduction, we analyse whether the training participation and task flexibility of low-skilled workers contribute to their firm-internal and external employability. In these analyses it is important, however, to distinguish between the different ways in which workers can remain attractive in the labour market. For instance, Groot and Maassen van den Brink (2000) distinguish between workers' internal and external employability. External employability refers to the ability and willingness to switch to a similar or another job in another firm, and therefore reflects the value of workers' human capital in the external labour market. Internal employability refers to a worker's ability and willingness to remain employed with the current employer, that is, the value of a worker's human capital in the internal labour market. Here we further distinguish between two groups of internally employable workers: those who remain employed in the same job and those who change jobs within the current firm. We therefore, distinguish between three forms of employability, namely job-match employability, which refers to workers who remain employed in their current job within their current firm; firm-internal employability, which refers to workers who switch to another job within their current firm; and external employability, which refers to workers who switch to a job in another firm.

\section{Data}

The data we used for our empirical analysis were taken from the linked 1998 and the 2000 waves of the Dutch OSA Labour Supply Survey. For 1998 the 
total sample size was 4,780 observations. For 2000 the total sample size was 4,185 . For the empirical analysis in this paper, we selected the lower educated workers (ISCED 0-2) aged between 16 and 50 who were in paid employment at the time of interview in 1998, who had a permanent contract in 1998 and who participated in both the 1998 and 2000 surveys[4]. This reduced the total sample size to 474 . Of these, 92 work in manufacturing and 158 in the services sector. The remaining 224 persons work in other sectors, such as agriculture and fisheries, education or health.

\section{Expected labour market position in five years}

We indicate the perceived employability of low-skilled workers in The Netherlands by the labour market position they expected to have in five years. For this indicator we used the following question in the 1998 survey:

If you look five years ahead, what will your position in the labour market be?

For this question, eight replies were possible:

- working in a similar job in this firm (job-match employability),

- working in a different job in this firm (firm-internal employability),

- working in a similar job in another firm (external employability),

- working in another job in another firm (external employability),

- unemployed,

- resigned,

- disabled/unable to work,

- retired, and

- don't know.

This indicator clearly indicates workers' expectations regarding their future labour market position.

Table I shows that practically all the low-skilled workers thought that they would remain active in the labour market for the next five years. Only about 2 per cent expected to be without a job in five years. In this sense it can be concluded that the low-skilled workers in The Netherlands who have permanent contracts are rather optimistic about their overall (i.e. internal and external) employability. Table I also shows that the majority of the low-skilled workers expected to be working in their current or a similar job within the current firm five years on (73 per cent). About 15 per cent of the workers expected to change jobs within the current firm and about 10 per cent expected to leave their current firm to start working elsewhere. This indicates that the great majority of the low-skilled workers rely on their firm-internal labour market.

Table I also shows that workers aged between 16 and 34 years were more likely to expect to leave their current job within the next five years than older workers. More than 80 per cent of the 45- to 50-year-old workers expected not to
Training, task flexibility and employability 
IJM

25,1

78

\section{Table I.}

Expected labour market position of lower educated workers five years from 1998

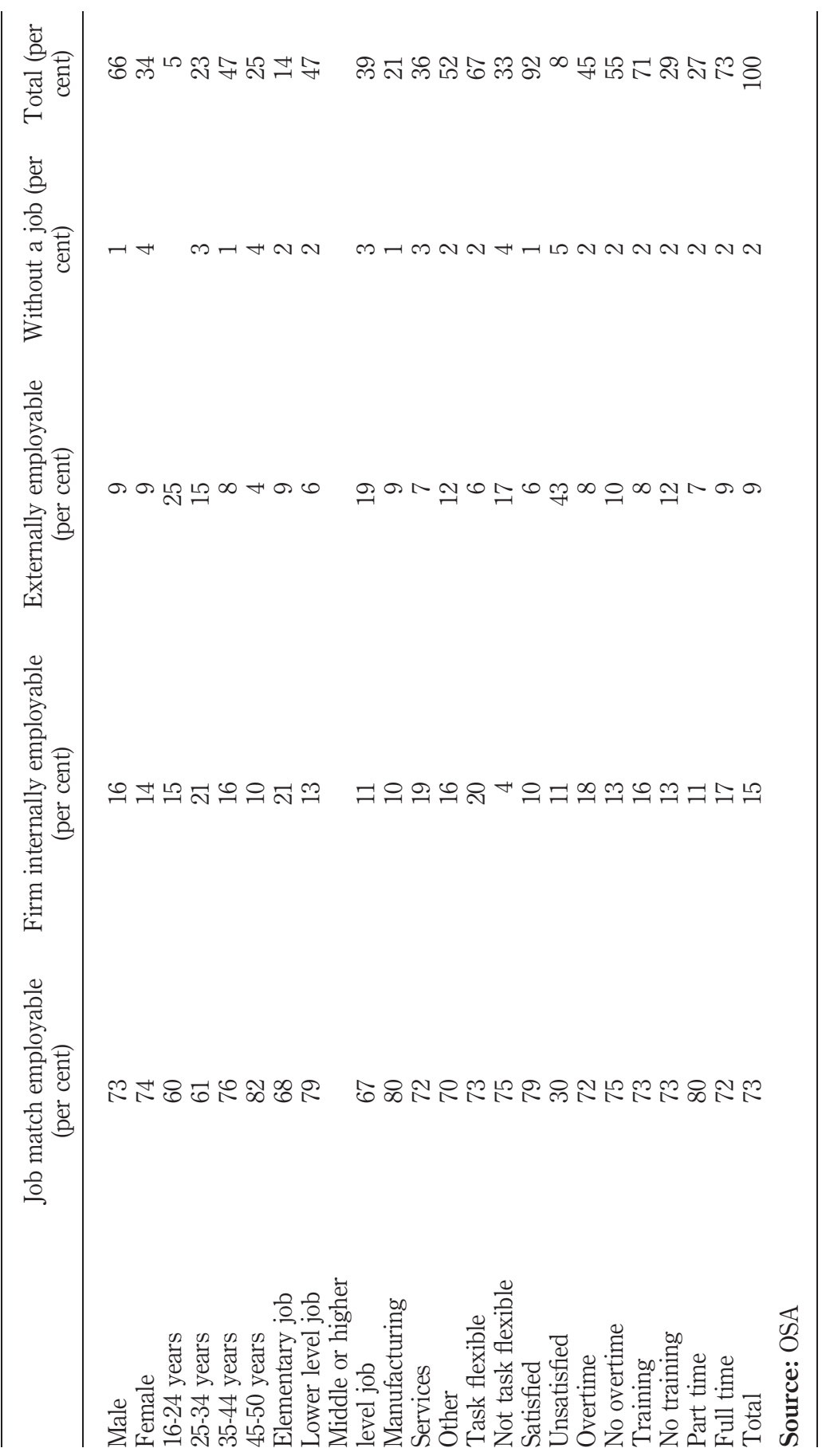


leave their current job within five years, compared to 60 per cent of the youngest categories of workers. This probably reflects the job search process at the beginning of workers' careers (Neil, 1999; Topel and Ward, 1992). It also reflects the idea that older workers are less mobile than their younger colleagues, either because of a higher rate of firm-specific human capital or a stronger aversion to change among older workers (Becker, 1964; Salthouse, 1991), or because employers who recruit new workers would rather invest in a younger worker's human capital than in that of an older worker (Gallup, 1990). The table also shows that low-skilled workers who are employed in services are more likely to expect to be firm-internally employable than are the low-skilled workers in manufacturing.

Low-skilled workers who are doing tasks that are not part of their job are considerably more likely to expect to change jobs within their current firm than are workers who are not task flexible. On the other hand, non-task flexible workers are far more likely to expect to leave their current firm than task flexible workers are. This suggests that low-skilled workers signal their task flexibility to increase their firm-internal employability. The same applies to, though to a far lesser degree, low-skilled workers who participate in training. Of these workers, 16 per cent thought that they would switch to another job within their current firm within the next five years, compared to 13 per cent of the low-skilled workers who did not participate in training. More striking, however, is that whether or not low-skilled workers participated in training had no effect on their expectations that they would stay in or leave their current job. Moreover, it shows that more than one-fifth of the low-skilled workers did not have the idea that it is important for them to participate in training to reduce the risk of losing their job due to skill obsolescence (de Grip and van Loo, 2002).

Furthermore, Table I shows that workers who are dissatisfied with their job are far more likely to expect to leave their job than are workers who are satisfied. It is surprising, however, that no less than 30 per cent of the low-skilled workers who were not satisfied still expected to remain employed in their current job with their current employer for another five years. This suggests that these workers might feel insecure about their labour market value or that they feel stuck in their current position, which might contribute to their dissatisfaction. The data also show that 43 per cent of the workers who were not satisfied with their current job expected to leave the firm where they work, whereas only 11 per cent expected "just" to change to another job in the firm-internal labour market. This suggests that workers' dissatisfaction is more often related to the firm as a whole than to their specific job.

Finally, Table I shows that low-skilled workers who have full-time contracts are less likely to expect to remain employed in their current job than those who work part-time. This is quite surprising, as one might expect workers who have a part-time contract to feel less secure about their job than those who have a full-time contract. However, since our data only refer to workers with
Training, task flexibility and employability 
IJM

25,1

80 permanent contracts, one might also interpret this finding as a confirmation of the idea that part-timers who prefer to work part time to combine work and care will opt for job security and are probably less mobile in the labour market.

\section{Estimation results}

In this section, we analyse whether the training participation and task flexibility of low-skilled workers affect their firm-internal or firm-external employability. First, we present the estimation results of a multinomial logit analysis on the effects of the training participation and task flexibility of low-skilled workers on their employability expectations, in terms of the three types of employability we distinguish (job-match employability, firm-internal employability, external employability). Next, we analyse whether the expectations the workers had in 1998 had been realised in 2000, by performing a multinomial logit analysis on the actual changes in the labour market position of low-skilled workers during the period 1998-2000. Finally, we analyse whether workers' employability expectations in 1998 affected their training participation and task flexibility during the period 1998-2000. These two binomial logit analyses enable us to show whether or not low-skilled workers invest in training and demonstrate their task flexibility to increase their chances of realising their employability expectations.

\section{The determinants of low-skilled workers' employability expectations}

We first analyse whether the employability expectations the low-skilled workers had in 1998 were affected by their training participation and task flexibility in the two years before they expressed their expectations. For this analysis we use the following two independent variables:

(1) training - participation in courses (1994-1998)[5], and

(2) task flexibility - tasks performed outside one's job (1996-1998).

Moreover, we include three dummy variables that indicate the quality of the job the low-skilled workers have:

- whether a worker is satisfied in his/her current job;

- whether a worker works overtime; and

- whether a worker has a part-time contract.

We also include a number of covariates, namely gender, age, sector of industry, professional level and tenure (see Appendix Table AI for a list of variables).

The estimation results in Table II show that whether or not a low-skilled worker participated in training between 1994 and 1998 has no effect on their perceptions of their employability. Neither the likelihood of workers expecting to change jobs within their current firm nor the likelihood of workers expecting to leave their current firm entirely is affected by previous training participation. 


\begin{tabular}{|c|c|c|c|}
\hline & $\beta$ & Standard error & \multirow{2}{*}{$\begin{array}{l}\text { flexibility and } \\
\text { employability }\end{array}$} \\
\hline \multicolumn{3}{|l|}{ External employability } & \\
\hline Intercept & 1.66 & 1.05 & \\
\hline Training & 0.16 & 0.51 & \\
\hline Task flexibility & $-1.24 * *$ & 0.44 & \\
\hline Satisfaction & $-2.50 * *$ & 0.57 & 8 \\
\hline Overtime & 0.51 & 0.45 & \\
\hline Part time & 0.31 & 0.67 & \\
\hline Male & $1.20 *$ & 0.71 & \\
\hline Age & $-0.48 *$ & 0.26 & \\
\hline Elementary level job & REF & REF & \\
\hline Lower level job & $-1.47 * *$ & 0.64 & \\
\hline Middle or higher level job & -0.64 & 0.62 & \\
\hline Manufacturing sector & -0.25 & 0.53 & \\
\hline Services sector & -0.20 & 0.53 & \\
\hline Tenure & $-0.07 *$ & 0.04 & \\
\hline \multicolumn{4}{|l|}{ Firm-internal employability } \\
\hline Intercept & -1.09 & 1.03 & \\
\hline Training & 0.33 & 0.38 & \\
\hline Task flexibility & $1.78^{* *}$ & 0.55 & \\
\hline Satisfaction & $-1.37 * *$ & 0.57 & \\
\hline Overtime & 0.21 & 0.32 & \\
\hline Part time & -0.67 & 0.51 & \\
\hline Male & -0.23 & 0.46 & \\
\hline Age & $-0.65^{* *}$ & 0.22 & \\
\hline Elementary job & REF & REF & \\
\hline Lower level job & 0.33 & 0.57 & \\
\hline Middle or higher level job & 0.80 & 0.58 & \\
\hline Manufacturing sector & -0.71 & 0.45 & \\
\hline Services sector & $0.68^{*}$ & 0.36 & \\
\hline Tenure & -0.02 & 0.03 & Table II. \\
\hline-2 Log-likelihood $=$ & 449.26 & - & Multinomial logit \\
\hline$\chi^{2}=$ & 92.84 & - & estimation of low-skilled \\
\hline$N=$ & 379 & - & workers' self-assessed \\
\hline$D f=$ & 24 & - & employability (reference \\
\hline \multicolumn{3}{|c|}{$\begin{array}{l}\text { Notes: *Significant at the } 10 \text { per cent level; } \\
\text { **significant at the } 5 \text { per cent level }\end{array}$} & $\begin{array}{l}\text { category: same job, } \\
\text { same firm in five years) }\end{array}$ \\
\hline
\end{tabular}

Task flexibility, however, rather strongly affects workers' employability. Task flexible workers expected that they would change jobs within their current firm rather than to remain employed in their current job, but expected to have a smaller chance to leave their current firm than to remain employed in their current job. This suggests that workers who perform tasks that are not part of their job have the idea that this contributes to their chances to move to another job in the firm-internal labour market.

Table II also shows that lower skilled workers who have a low-level job (i.e. above the elementary level) are less likely to expect to leave their current job 
IJM

25,1

82

and firm within five years than workers who have an elementary job. This indicates that low-skilled workers with a low-level job have a higher job-match employability than the low-skilled workers who are employed in the elementary jobs.

In addition, Table II shows that there is a strong negative relationship between workers' job satisfaction and their firm-internal employability expectations. However, the negative relationship between job satisfaction and the chance of a worker expecting to leave the firm entirely is even stronger. We conclude, therefore, that dissatisfied workers are more likely to expect to leave their current firm and not just their current job.

Low-skilled workers who are employed in the services sector are more likely to expect to change jobs within their current firm. This indicates that the low-skilled workers who are employed in the service sectors have a relatively high firm-internal employability.

Table II also shows that the older the workers are, the less likely it is that they expect to leave their current job or their current firm within the next five years. Apparently, older workers gradually lose faith in their external and firm-internal employability. They rely mainly on remaining employed in their current job. Tenure adds to these findings. The longer the workers have worked in their current job, the less likely they are to expect to be externally employable. However, tenure has no significant effect on whether or not a worker expects to change jobs within the firm. Finally, male workers are more likely to expect to leave their current firm within the next five years than female workers.

Do workers realise their employability expectations?

In order to establish whether or not workers' medium-term employability expectations in 1998 had already been realised in 2000[6], we analysed the determinants of the actual changes in the workers' labour market position during the period 1998-2000 by means of a multinomial logit analysis. The dependant variable in this analysis is the effectuation of a worker's employability in the first two years, in which we again distinguish between a worker's firm-internal employability, external employability and - as a reference - job-match employability.

In order to analyse whether the changes in a worker's labour market position are in accordance with their employability expectations, we used the following independent variables.

(1) Employability expectation: expected labour market situation in five years.

- job-match employability,

- firm-internal employability, and

- external employability (1998).

(2) Training 1994-1998: participation in courses (1994-1998). 
(3) Training 1998-2000: participation in courses (1998-2000).

(4) Task flexibility 1996-1998: tasks performed outside own job (1996-1998).

(5) Task flexibility 1998-2000: tasks performed outside own job (1998-2000).
Training, task flexibility and employability

Moreover, as in our first analysis, we include the variables on workers' job satisfaction, overtime work and part-time work, and the covariates gender, age, sector of industry, job level and tenure (all variables refer to the situation in 1998).

Table III shows that low-skilled workers who in 1998 expected to move to another job within the firm where they were employed were indeed significantly more likely to have another job within the firm by the year 2000. This indicates that workers' expectations regarding their firm-internal employability were realistic. However, low-skilled workers who considered themselves externally employable in 1998 were also significantly more likely to change job within the firm than were workers who expected to remain in the same job. Surprisingly, the workers who in 1998 expected to leave the firm within five years were no more likely to have left the firm in the first two years than were the workers who in 1998 expected to remain employed in their job for another five years. One possible explanation for this is that finding a new job outside the firm is more difficult and at least takes more time than finding one inside the firm, and that workers who consider themselves externally employable use inside options as an alternative to outside options that might be more difficult to realise.

Table III also shows that low-skilled workers who participated in training in the period 1998-2000 were significantly more likely to move to another job within the firm. Since participation in training during the period 1994-1998 had no such effect, low-skilled workers probably mainly participate in training just before they change jobs internally, or even after the job change[7]. Workers' task flexibility, however, does not have an additional effect on the extent to which low-skilled workers effectuate their employability.

Furthermore, Table III also shows a significant negative effect of job tenure on the external employability of low-skilled workers and a significant positive effect of job tenure on workers' firm-internal employability. This indicates the firm-specific skills that the workers acquire in the course of their careers or the seniority rules in the internal labour market.

Finally, Table III shows that male workers were more likely to leave the firm where they work than female workers. Also, workers in the services sector were less likely to leave their firm than workers in other sectors of the economy. However, the low-skilled workers who are employed in services did not realise their higher firm-internal employability expectations. 
External employability

Intercept

1.32

0.93

Expected firm-internal employability

0.45

0.45

Expected firm-external employability

0.85

0.52

Expected job-match employability

REF

REF

Training (1994-1998)

0.01

0.37

Training (1998-2000)

$-0.07$

0.32

Task flexibility (1996-1998)

$-0.17$

0.35

Task flexibility (1998-2000)

$-0.30$

0.33

Satisfaction

$-0.79$

0.56

Overtime

0.32

Part time

0.07

0.45

Male

Age

Elementary job

Lower level job

Middle or higher level job

Manufacturing sector

Services sector

Tenure

Firm-internal employability

Intercept

Expected firm-internal employability

Expected firm-external employability

0.17

0.44

$-0.73^{*}$

0.20

REF

REF

$\begin{array}{ll}-0.03 & 0.47\end{array}$

$\begin{array}{ll}-0.52 & 0.50\end{array}$

$\begin{array}{ll}-0.49 & 0.42\end{array}$

$\begin{array}{ll}-0.73^{* *} & 0.37\end{array}$

$-0.12^{* *} \quad 0.04$

Expected job-match employability

Training (1994-1998)

Training (1998-2000)

Task flexibility (1996-1998)

Task flexibility (1998-2000)

$\begin{array}{ll}-3.20 * * & 1.26\end{array}$

$1.698 * * \quad 0.43$

$1.252 * * * 63$

REF REF

$\begin{array}{ll}-0.67 & 0.43\end{array}$

$0.84^{* *} \quad 0.37$

$\begin{array}{ll}-0.30 & 0.44\end{array}$

$\begin{array}{ll}0.08 & 0.39\end{array}$

Satisfaction

0.70

Overtime

0.21

0.38

Part time

0.21

0.53

Male

0.42

0.51

Age

$-0.77$

0.24

Elementary job

0.07

$\mathrm{REF}$

Lower level job

REF

0.66

Middle or higher level job

0.37

0.66

Manufacturing sector

0.77

0.49

Services sector

0.42

Tenure

Multinomial logit estimation of low-skilled workers' employability effectuation (reference category: job-match employability, i.e. no changes)

-2 Log-likelihood $=$

$\chi^{2}=$
$N=$

$D f=$
0.23

0.22

$0.06^{* *}$

511.74

82.37

365

32

Notes: *Significant at the 10 per cent level;

**significant at the 5 per cent level 
The effect of workers' employability expectations on training participation and task flexibility

One may wonder whether low-skilled workers deliberately participate in training and demonstrate their task flexibility to increase their chances of realising their firm-internal or external employability expectations[8]. Therefore, we analysed by means of two binomial logit analyses whether the employability expectations of low-skilled workers have any effect on their training participation or task flexibility. Table IV shows that low-skilled workers who expected to have a high firm-internal employability were more likely to participate in training courses than workers who expected to remain employed in the same job and the workers who expected to have a high external employability. Since the low-skilled workers who participate in training are more likely to move to another job in the firm-internal labour market than are workers who do not participate in training (see Table III), we conclude that low-skilled workers' training participation is indeed a vehicle by which they manage to increase their chances of realising their firm-internal employability expectations.

Table IV also shows that the employability expectations of the low-skilled workers have no effect on their task flexibility. This indicates that low-skilled workers do not consider their task flexibility as a tool to increase their chances of realising their employability expectations, although it might also be possible that they cannot signal their task flexibility in the jobs they have.

\section{Conclusions and discussion}

In this paper, we analysed whether the training participation and task flexibility of low-skilled workers contribute to their firm-internal and firm-external mobility. We found that both workers' training participation and task flexibility merely contribute to workers' firm-internal employability. However, the workers' participation in training plays a much more explicit role in their firm-internal careers than their task flexibility. Workers who demonstrate a large degree of task flexibility indeed expect to have a large degree of firm-internal employability. The latter, however, does not induce them to demonstrate their task flexibility more often, and their task flexibility does not increase their chances of realising their firm-internal employability expectations. On the other hand, workers' participation in training does not increase their firm-internal employability expectations. In practice, however, participation in training increases a worker's chances of moving to another job in the firm-internal labour market, whereas we also found that workers who think they are firm-internal employable are more likely to participate in the training courses.

Neither participation in training nor task flexibility contributes to the external employability of low-skilled workers. Task-flexible low-skilled workers are less likely to expect to be externally employable than non-task
Training, task flexibility and employability

85 
Training participation (1998-2000)

Intercept

$\begin{array}{ll}-1.46^{* *} & 0.68\end{array}$

Expected firm-internal employability

$0.82^{* *} \quad 0.31$

Expected firm-external employability

0.03

0.41

Expected job-match employability

$\mathrm{REF}$

REF

Training (1994-1998)

$0.91^{* *} \quad 0.27$

Satisfaction

0.23

0.45

Overtime

$-0.04$

0.23

Part-time

Male

Age

Elementary job

0.36

0.36

$0.72^{* * *} \quad 0.35$

Lower level job

0.14

$-0.22$

$\mathrm{REF}$

Middle or higher level job

0.37

Manufacturing sector

0.38

Services sector

0.29

Tenure

-2 Log-likelihood $=$

0.17

0.12

0.27

0.18

0.02

$\chi^{2}=$

$N=$

$D f=$

$-0.01$

494.68

$32.98^{* * *}$

365

13

Task flexibility (1998-2000)

Intercept

0.95

0.76

Expected firm-internal employability

0.14

0.35

Expected firm-external employability

0.37

0.47

Expected job-match employability

$\mathrm{REF}$

REF

Task flexibility (1996-1998)

0.45

0.27

Satisfaction

0.28

0.48

Overtime

$-0.32$

0.25

Part-time

$-0.31$

0.38

Male

$-0.42$

0.38

Age

Elementary job

$-0.26$

0.16

Lower level job

$\mathrm{REF}$

$\mathrm{REF}$

Middle or higher level job

0.63

0.39

Manufacturing sector

0.58

0.39

0.26

0.33

Services sector

$-0.34$

0.28

Tenure

$-0.02$

0.02

estimation of low-skilled

-2 Log-likelihood $=$

428.12

$\chi^{2}=$

16.96

$N=$

365

$D f=$

13

flexibility (reference categories: no training and no task flexibility)

Notes: *Significant at the 10 per cent level; **significant at the 5 per cent level 
flexible workers. This shows that low-skilled workers' task flexibility is merely a firm-internal employability enhancing practice that might reduce their scope of opportunities in the external labour market. Participation in training does not seem to play any role in workers' perceptions of their external employability or with respect to their actual external employability. These results can probably be explained by the conclusions drawn by de Grip and Wolbers (2002), who found that low-skilled workers usually have more opportunities to improve their position in the firm-internal labour market than they do in the external labour market. This is also shown by our finding that the low-skilled workers who found themselves externally employable were more likely to move to another job in the internal labour market instead of realising their external employability expectations.

\section{Notes}

1. The extent to which workers can determine their training participation and task flexibility of course also depends on the "effectuation conditions" offered to them.

2. See de Grip et al. (2004) for a more comprehensive overview of the literature on employability.

3. See note 1 .

4. We excluded the workers who were older than 50, since in The Netherlands these workers have a fair chance that within five years they will leave the labour market. Moreover, we excluded workers with a temporary contract because these workers will almost automatically leave their current job in the next few years, whereas this does not reflect a strong labour market position as is shown in van Loo et al. (2001).

5. Here we had to use the data for the period 1994-1998 as we did not have the data for the period 1996-1998 only.

6. We do not have the data to analyse this relation for a longer period.

7. Our results confirm the results of de Grip et al. (1998), who found a direct relation (i.e. without considering workers' employability expectations) between workers' participation in training and their firm-internal mobility, whereas they did not find a correlation between workers' training participation and their external mobility.

8. See note 1.

\section{References}

Arthur, M.B. (1994), "The boundaryless career: a new perspective for organizational inquiry", Journal of Organizational Behaviour, Vol. 15, pp. 295-306.

Becker, G. (1964), Human Capital: A Theoretical and Empirical Analysis, with Special Reference to Education, National Bureau of Economic Research, New York, NY.

Bloch, S. and Bates, T. (1995), Employability, Your Way to Career Success, Kogan Page, London.

Borghans, L. and de Grip, A. (2000), "Skills and low pay: upgrading or over-education?", in Gregory, M., Salverda, W. and Bazen, S. (Eds), Labour Market Inequalities, Problems and Policies of Low Wage Employment in International Perspective, Oxford University Press, Oxford, pp. 198-223.

Bridges, W. (1994), Jobshift, How to Prosper in a Workplace without Jobs, Addison-Wesley, Reading, MA.
Training, task flexibility and employability 
IJM

25,1

88

Charner, I. (1988), "Employability credentials: a key to successful youth transition to work", Journal of Career Development, Vol. 15 No. 1, pp. 30-40.

de Grip, A. and van Loo, J. (2002), “The economics of skills obsolescence: a review”, in de Grip, A., van Loo, J. and Mayhew, K. (Eds), Research in Labor Economics, Understanding Skills Obsolescence, Vol. 1, JAI Press, Amsterdam/Boston, MA, pp. 1-26.

de Grip, A. and Wolbers, M. (2002), Are Low-skilled Workers Better off in Countries where Internal Labour Markets Dominate?, ROA, Maastricht, mimeo.

de Grip, A., Heijke, H. and Willems, E. (1998), “Training and mobility”, The Netherlands' Journal of Social Sciences, Vol. 34 No. 1, pp. 78-98.

de Grip, A., van Loo, J. and Sanders, J. (2004), "The industry employability index: taking account of supply and demand characteristics", International Labour Review, Vol. 143 No. 1.

Gallup, J.L. (1990), Ageism: The Problem of the 1990s, Brookstreet Employment Bureau, London.

Groot, W. and Maassen van den Brink, H. (2000), "Education, training and employability", Applied Economics, Vol. 32, pp. 573-81.

Hoyt, K.B. (1978), "Employability: are the schools responsible?", New Directions for Education and Work: Reassessing the Link between Work and Education, pp. 29-33.

Hyatt, C. (1995), Lifetime Employability: How to Become Indispensable, Mastermedia Limited, New York, NY.

Levy, J.M., Jessop, D.J., Rimmerman, A. and Levy, P.H. (1992), "Attitudes of Fortune 500 corporate executives toward the employability of persons with severe disabilities: a national survey", Mental Retardation, Vol. 30 No. 2, pp. 67-75.

Mangum, G.L. (1976), Employability, Employment and Income, Olympus, Salt Lake City, UT.

Neil, D. (1999), “The complexity of job mobility among young men”, Journal of Labor Economics, Vol. 17, pp. 237-61.

Outin, J.L. (1990), “Trajectoires professionnelles et mobilité de la main-d’œuvre: la construction sociale de l'employabilité", Sociologie du Travail, Vol. 32 No. 4, pp. 469-89.

Salthouse, T.A. (1991), Theoretical Perspectives on Cognitive Ageing, Erlbaum, Hillsdale, NJ.

Shields, M. (1998), "Changes in the determinants of employer-funded training for full-time employees in Britain", Oxford Bulletin of Economics and Statistics, Vol. 60, pp. 189-214.

Soloff, A. and Bolton, B.F. (1969), "The validity of the CJVS scale of employability for older clients in a vocational adjustment workshop", Educational and Psychological Measurement, Vol. 29, pp. 993-8.

Thijssen, J.G.L. (1997), "Employability en employment: terminologie, modelvorming en opleidingspraktijk", Opleiding en ontwikkeling, Vol. 10 No. 10, pp. 9-14.

Topel, R.H. and Ward, M.P. (1992), "Job mobility and the careers of young men”, Quarterly Journal of Economics, Vol. 107, pp. 439-79.

Tseng, M.S. (1972), "Self-perception and employability: a vocational rehabilitation problem", Journal of Counselling Psychology, Vol. 19 No. 4, pp. 314-17.

van Loo, J., de Grip, A. and de Steur, M. (2001), "Skills obsolescence: causes and cures", International Journal of Manpower, Vol. 22 No. 1/2, pp. 121-37.

\section{Further reading}

Dekker, R., de Grip, A. and Heijke, H. (2002), "The effects of training and over-education on career mobility in a segmented labour market", International Journal of Manpower, Vol. 23 No. 2, pp. 106-25.

Doeringer, P. and Piore, M. (1971), Internal Labour Markets and Manpower Analysis, Heath, Lexington, MA. 
Appendix

\begin{tabular}{l} 
Variable \\
\hline External employability \\
Firm-internal employability \\
Job-match employability \\
Expected firm-external employ \\
Expected firm-internal employ \\
Expected job-match employabilt \\
Training (1994-1998) \\
No training (1994-1998) \\
Training (1998-2000) \\
No training (1998-2000) \\
Task flexibility (1996-1998) \\
No task flexibility (1996-1998) \\
Task flexibility (1998-2000) \\
No task flexibility (1998-2000) \\
Satisfaction \\
No satisfaction \\
Overtime \\
No overtime \\
Part-time \\
Not part-time \\
Male \\
No male \\
Age \\
Elementary job \\
Lower level job \\
Middle or higher level job \\
Manufacturing sector \\
Services sector \\
Other \\
Tenure
\end{tabular}

Definition

Changed firms (1998-2000)

Changed jobs within the firm (1998-2000)

No changes in labour market position (1998-2000)

Expects to change firms within five years (1998)

Expects to change jobs within current firm within five years (1998)

Expects to remain employed in the same job for another five years (1998)

Participated in training between 1994 and 1998

Did not participate in training between 1994 and 1998

Participated in training between 1998 and 2000

Did not participate in training between 1998 and 2000

Performed tasks outside own job between 1996 and 1998

Did not perform tasks outside own job between 1996 and 1998

Performed tasks outside own job between 1998 and 2000

Did not perform tasks outside own job between 1998 and 2000

Satisfied/highly satisfied with job in 1998

Not that satisfied/not at all satisfied with job in 1998

Worked extra hours, either paid or unpaid in 1996, 1997 or 1998

Did not work extra hours in 1996, 1997 or 1998

Worked 32 or fewer hours per week in 1998

Worked more than 32 hours per week in 1998

Male

Female

Age in 1998

Had an elementary job in 1998

Had a lower-level job in 1998

Had a middle, higher or academic job in 1998

Worked in the manufacturing sector in 1998

Worked in the services sector in 1998

Worked in another sector in 1998

Number of years a worker had worked in the same job with the same employer in 1998
Training, task flexibility and employability

89
57

316

42

70

332

335

139

203

271

325

142

318

132

435

215

259

116

319

311

163

(474)

65

219

180

92

158

135

Table AI. 